\title{
Penerapan Model Discovery Learning dalam Meningkatkan Kemampuan Menulis Cerita Pendek bagi Mahasiswa Kursus Jurusan Akomodasi di Akademi Komunitas MAPINDO Tahun Ajaran 2019/2020
}

\author{
Nirmala Tari ${ }^{1}$, Ni Putu Dianita Safitri ${ }^{2}$ \\ Akademi Komunitas Manajemen Perhotelan Indonesia \\ nirmalatari23@yahoo.com ${ }^{1}$, tri18_nata@yahoo.com²
}

\begin{abstract}
ABSTRAK
Penelitian ini bertujuan untuk mengetahui apakah penerapan model discovery learning dapat meningkatkan kemampuan menulis cerita pendek bagi mahasiswa kursus jurusan Akomodasi di Akademi Komunitas MAPINDO tahun ajaran 2019/2020. Penelitian ini merupakan penelitian tindakan kelas dengan menggunakan 30 mahasiswa kursus jurusan Akomodasi sebagai subjek penelitian dengan mengumpulkan data dari hasil menulis cerpen mahasiswa. Maka data dikumpulkan dengan menilai cerpen yang ditulis oleh mahasiswa dengan fokus penilaian pada pada komponen yakni; (1) Tema, (2)Tokoh/penokohan, (3)Latar, (4) alur, (5) amanat/pesan. Data yang didapat kemudian diolah secara kuantitatif dengan mengikuti rubrik penilaian yang sudah divalidasi. Adapun hasil dari penelitian ini diketahui bahwa rata-rata nilai mahasiswa dalam menulis cerpen diatas nilai standar yakni 70. Hal itu membuktikan bahwa model discovery learning mampu meningkatkan kemampuan menulis cerpen dengan topic dan tema yang menyenangkan.
\end{abstract}

\section{Kata kunci: discovery learning, menulis, cerpen}

\section{PENDAHULUAN}

Pembelajaran Bahasa Inggris dewasa ini lebih menekankan kepada kemampuan peserta didik memanfaatkan Bahasa dalam kehidupan sehari-hari bukan lagi tentang teori kebahasaan. Pembelajaran Bahasa terdahulu yang hanya menekankan kepada materi teori kebahasaan hasilnya mahamahamahasiswa hanya sangat paham terhadap teori kebahasaan atau pola kalimat dan cara menyusun kalimat dan teks tanpa mengetahui konteks yang tepat. Dalam pembelajaran bahasa Inggris, penting bagi mahamahamahasiswa untuk menguasai empat skill, yang salah satunya adalah kemampuan menulis.

Menulis merupakan salah satu kompetensi yang harus dikuasai mahasiswa dalam mempelajari Bahasa Inggris. Terkait dengan hal tersebut, maka dalam proses pembelajaran juga hendaknya pengajar mampu mendesain pembelajaran yang mampu membuat mahasiswa terampil dalam menggunakan Bahasa. Kelemahan proses pembelajaran Bahasa Inggris yang terjadi selama ini, adalah rendahnya kemampuan mahasiswa menulis cerita pendek. Hal ini disebabkan karena pengajar kurang tepat memilih pendekatan, metode, model dan strategi pembelajaran berdasarkan karakteristik mahasiswa yang diajarnya, juga pengajar kurang mampu membuat mahasiswa aktif dalam setiap proses pembelajaran. Pengajar lebih cenderung berperan sebagai penyampai materi ajar ketimbang sebagai seorang pengajar sejati yang seharusnya bertugas sebagai pendidik dan pengajar.

Kompetensi yang harus segera ditanggulangi dalam Pembelajaran Bahasa Inggris, adalah menulis Cerita pendek yakni bahasa tertulis yang digunakan sebagai media untuk mengungkapkan pengalaman pribadi secara nyata yang pernah dialami langsung, pengalaman orang lain, ataupun hasil berimajinasi. Berdasarkan definisi tadi, 
Jurnal Manajemen Pelayanan Hotel Akademi Komunitas Manajemen Perhotelan Indonesia (Tari \& Safitri, halaman 113-121) Vol 3, No 2 Edisi Desember 2019

tujuan teks cerita pendek adalah untuk menambah dan menggugah motivasi, semangat, dan rasa percaya diri dalam berbahasa tulisan. Menulis Cerita pendek memang harus diakui sebagai sebuah aktivitas yang sangat berbeda bila dibandingkan dengan berbicara, membaca dan menyimak. Menulis Cerita pendek bukanlah kemampuan yang dapat dikuasai dengan sendirinya, melainkan harus melalui proses pembelajaran sehingga memang diperlukan sebuah proses panjang untuk menumbuhkembangkan tradisi menulis Cerita pendek.

Pembelajaran menulis cerita pendek kurang menarik bagi mahasiswa sehingga kemampuan inipun sangat rendah. Dengan demikian maka kemampuan menulis cerita pendek merupakan kompetensi wajib untuk ditingkatkan. Peningkatan kemampuan atau kompetensi dimaksud diupayakan dengan cara pembelajaran secara kontekstual, yakni pembelajaran dari oleh dan untuk mahasiswa, dengan menggunakan kondisi lingkungan maupun pengalamannya sebagai obyek dalam pembelajaran, sehingga keengganan mahasiswa belajar menulis Cerita pendek dapat ditanggulangi karena pembelajaran terkait dengan kehidupannya. Diharapkan pembelajaran Bahasa Inggris pada aspek menulis Cerita pendek menjadi menarik bagi mahasiswa.

Hasil pembelajaran menulis cerita pendek bagi mahasiswa kursus jurusan Akomodasi semester tiga di Akademi Komunitas MAPINDO masih belum memperoleh hasil yang memenuhi standar kelulusan. Perolehan data awal kursus tahun Pelajaran 2019/2020 terhadap kemampuan menulis cerita pendek baru mencapai nilai 60.00. Hasil tersebut masih dibawah standar minimal yang ditetapkan sebesar 70 .

Melihat kondisi tersebut, maka diupayakan untuk memperbaiki model pembelajaran dengan menggunakan Model Pembelajaran Discovery. Model pembelajaran ini menekankan agar mahasiswa mampu menemukan informasi dan memahami konsep pembelajaran secara mandiri berdasarkan kemampuan yang dimilikinya namun masih dibawah bimbingan dan pengawasan pengajar agar pembelajaran yang mereka dapatkan terbukti benar. Kelebihan model pembelajaran Discovery adalah pembelajaran berlangsung secara teratur mengikuti tahapan atau langkah-langkah yang benar, dapat disesuaikan dengan materi pelajaran yang akan disampaikan, membantu pengajar dalam berkreasi berbagai model pembelajaran secara bergantian dengan konsep materi yang sesuai pula.

Mahasiswa kursus jurusan akomodasi yang nantinya akan bekerja pada industri pariwisata. Pariwisata merupakan salah satu aspek kehidupan yang sangat berkembang di Bali (Tari \& Safitri, 2018). Bali sebagai tujuan wisata, bahasa Inggris juga perlu dipertimbangkan untuk mendukung keberhasilan komunikasi dengan wisatawan asing, bahasa inggris merupakan salah satu aspek penting dalam komunikasi. Bahasa Inggris ada sebagai bahasa global, oleh karena itu bahasa Inggris secara luas dianggap sebagai bahasa global (Anggayana, Nitiasih \& Budasi, 2016). Bahkan dikenal sebagai bahasa internasional (Asriyani, Suryawati \& Anggayana, 2019). Dalam meningkatkan kemampuan menulis diharapkan juga dapat meminimalisir kesalahan pada aspek tata bahasa atau grammar bahasa Inggris, seperti penggunaan bentuk tenses dalam kalimat (Lindawati, Asriyani \& Anggayana, 2018).

Tata bahasa atau dalam bahasa Inggris disebut dengan grammar adalah seperangkat peraturan yang terdapat dalam bahasa tertentu (Lindawati, Asriyani \& Anggayana, 2019). Memungkinkan mengembangkan kompetensi komunikatif mereka dalam empat keterampilan bahasa, yaitu keterampilan menyimak, berbicara, membaca dan menulis (Asriyani, Suryawati \& Anggayana, 2019). Walaupun di Indonesia terdiri dari berbagai dialek tidak menjadi halangan (Anggayana, Budasi \& Suarnajaya, 2014). Berbahasa Inggris saat 
Jurnal Manajemen Pelayanan Hotel Akademi Komunitas Manajemen Perhotelan Indonesia (Tari \& Safitri, halaman 113-121) Vol 3, No 2 Edisi Desember 2019

ini telah menjadi percakapan yang sering dilakukan oleh wisatawan asing (Anggayana, Budasi, \& Kusuma, 2019). Dalam pelayanan tersebut, fasilitas dan kualitas pelayanan menjadi ujung tombak dalam hal pemberian kesan baik terhadap pelayanan (Anggayana \& Sari, 2018). Dalam industri pariwisata budaya dimasukkan ke dalamnya (Redianis, Putra \& Anggayana, 2019).

Sektor pariwisata mampu menyediakan ekonomi, sosial dan budaya yang bermanfaat bagi semua pelaku pariwisata stakeholders (Osin, Pibriari \& Anggayana, 2019). Tidak mengherankan bahwa industri pariwisata menjadi sektor ekonomi utama, di mana sebagian besar orang bekerja di industri pariwisata (Budasi \& Anggayana, 2019). Pada dasarnya, kemajuan suatu bangsa sangat ditentukan oleh kualitas pendidikan penduduknya (Anggayani \& Osin, 2018). Sektor pariwisata terus digalakkan karena sektor ini merupakan andalan dalam menghasilkan pendapatan masyarakat serta devisa bagi negara (Suryawati, \& Osin, 2019). Dengan berkembangnya suatu industri pariwisata akan berpengaruh kepada meningkatnya pendapatan masyarakat sekitar obyek wisata serta terciptanya lapangan kerja (Osin, Kusuma, \& Suryawati, 2019).

Adapun manfaat dari penelitian ini adalah pembelajaran menjadi sangat menarik sehingga dapat meningkatkan prestasi belajar utamanya kemampuan menulis Cerita pendek. Selain itu, manfaat juga dirasakan oleh pengajar. Pengajar memiliki berbagai pengalaman dan kemampuan memanfaatkan berbagai model pembelajaran yang efektif dalam upaya meningkatkan profesionalitas, karena dapat mengatasi masalah-masalah yang terjadi dalam mengemban tugas profesinya.

\section{KAJIAN PUSTAKA}

Discovery Learning adalah proses pembelajaran yang menjadikan peserta didik harus berperan aktif dalam belajar di kelas. Bruner memakai metode yang disebutnya Discovery Learning, dimana murid mengorganisasi bahan yang dipelajari dengan suatu bentuk akhir (Dalyono, 1996:41). Pada Discovery Learning, mahasiswa belajar memahami konsep, arti, dan hubungan, melalui proses intuitif untuk akhirnya sampai kepada suatu kesimpulan (Budiningsih, 2005:43).

Discovery Learning merupakan pembentukan kategori-kategori atau konsep-konsep, yang dapat memungkinkan terjadinya generalisasi. Sebagaimana teori Bruner tentang kategorisasi yang nampak dalam Discovery, bahwa Discovery adalah pembentukan kategori-kategori, atau lebih sering disebut sistem-sistem coding. Pembentukan kategori-kategori dan sistemsistem coding dirumuskan demikian dalam arti relasi-relasi (similaritas \& difference) yang terjadi diantara obyek-obyek dan kejadian-kejadian (events).

Proses aplikasi model Discovery Learning, pengajar berperan sebagai pembimbing dengan memberikan kesempatan kepada mahasiswa untuk belajar secara aktif, sebagaimana pendapat mahasiswa harus dapat membimbing dan mengarahkan kegiatan belajar mahasiswa sesuai dengan tujuan (Sardiman, 2005:145). Kondisi seperti ini ingin merubah kegiatan belajar mengajar yang teacher oriented menjadi student oriented. Hal yang menarik dalam pendapat Bruner yang menyebutkan: hendaknya pengajar harus memberikan kesempatan peserta didiknya untuk menjadi seorang problem solver, seorang scientis, historin, atau ahli matematika. Dalam Discovery Learning bahan ajar tidak disajikan dalam bentuk akhir, mahasiswa dituntut untuk melakukan berbagai kegiatan menghimpun informasi, membandingkan, mengkategorikan, menganalisis, mengintegrasikan, mereorganisasikan bahan serta membuat kesimpulan-kesimpulan.

Hal tersebut memungkinkan peserta didik menemukan arti bagi diri mereka sendiri, dan memungkinkan mereka untuk mempelajari konsep-konsep di dalam bahasa yang dimengerti mereka. Dengan demikian seorang pengajar dalam aplikasi 
Discovery Learning harus dapat
menempatkan mahasiswa pada kesempatan-kesempatan dalam belajar yang lebih mandiri. Bruner mengatakan bahwa proses belajar akan berjalan dengan baik dan kreatif jika pengajar memberikan kesempatan kepada peserta didik untuk menemukan suatu konsep, teori, aturan, atau pemahaman melalui contoh-contoh yang ia jumpai dalam kehidupannya (Budiningsih, 2005:41).

Menurut pendapat Burhan Nurgiyantoro (2001: 273), menulis adalah aktivitas mengungkapkan gagasan melalui media bahasa. Menulis merupakan kegiatanproduktif dan ekspresif sehingga penulis harus memiliki kemampuan dalam menggunakan kosakata, tata tulis, dan struktur bahasa. Atar Semi (1993: 47), mengartikan keterampilan menulis sebagai tindakan memindahkan pikiran dan perasaan ke dalam bahasa tulis dengan menggunakan lambang-lambang. Senada dengan pendapat tersebut, menurut Harris (Ahmad Rofi'uddin danDarmiyati Zuhdi, 1999: 276) keterampilan menulis diartikan sebagai kemampuan menggunakan bahasa untuk menyatakan ide, pikiran atau perasaan kepada orang lain dengan menggunaan bahasa tulis. Menulis merupakan aktivitas pengekpresian ide, gagasan, pikiran atau perasaan ke dalam lambang-lambang kebahasaan. Sedangkan menurut Suparno dan Mohammad Yunus (2008:1.3), menulis merupakan kegiatan menyampaikan pesan (komunikasi) dengan mengunakan bahasa tulis sebagai media atau alatnya. Tujuan menulis adalah agar pembaca mengetahui, mengerti dan memahami nilai-nilai dalam sebuah tulisan sehingga pembaca ikut berpikir, berpendapat atau melakukan sesuatu yang berhubungan dengan isi tulisan.

Cerpen atau cerita pendek merupakan jenis karya sastra yang dijelaskan dalam bentuk tulisan yang berwujud sebuah cerita atau kisah secara pendek, jelas, serta ringkas. Selain itu cerpen juga dapat disebut dengan sebuah prosa fiksi yang isinya mengenai pengisahan yang hanya terfokus pada satu konflik atau permasalahan. Untuk lebih singkatnya cerpen ialah cerita pendek yang hanya verpusat pada satu konflik saja, namun ternyata masih ada opini lain yang mengenai cerpen yakni pengertian cerpen menurut para ahli, nah untuk lebih jelasnya simak saja uraian dibawah ini.

Ada beberapa pengertian cerpen menurut para ahli yang diantaranya yaitu: Menurut Nugroho Notosusanto Dalam Tarigan menyatakan bahwa Cerpen merupakan kisah cerita pendek mulai dari 5000 kata-kata atau memperkirakan $17 \mathrm{pp}$ kuarto spasi ganda dan berpusat pada dirinya sendiri. Selanjutnya menurut Hendy; Cerita pendek merupakan sebuah cerita pendek yang berisi narasi tungal. Menurut J.S Badudu; Cerpen merupakan cerita yang menjurus dan kosentrasi yang berpusat pada satu peristiwa yaitu peristiwa yang menumbuhkan peristiwa itu sendiri. Ada beberapa cirri-ciri cerpen yang diantaranya yaitu: Bentuk tulisan yang singkat tentunya lebih pendek dari novel. Isi dari cerita berasal dari kehidupan sehari-hari. Cerpen terdiri kurang dari 10.000 kata. Penggunaan kata-kata yang mudah dipahami oleh pembaca. Mengangkat beberapa peristiwa saja dalam hidup tidak seluruhnya. Kesan dan pesan yang ditinggalkan sangatlah mendalam sehingga si pembaca ikut merasakan isi dari cerpen tersebut. Cerpen bersifat fiktif. Cerpen hanya memiliki 1 alur.

\section{METODE PENELITIAN}

Jenis penelitian yang digunakan dalam menanggulangi permasalahan yang terjadi pada kelas tempat melaksanakan proses pembelajaran adalah penelitian tindakan dimana menurut Kemmis dan Taggart menyatakan bahwa "Penelitian Tindakan adalah suatu bentuk penelitian reflektif 
diri secara kolektif dilakukan peneliti dalam situasi sosial untuk meningkatkan penalaran dan keadilan praktik pendidikan sosial mereka, serta pemahaman mereka mengenai praktik dan terhadap situasi tempat di mana dilakukan praktik-praktik tersebut". Penelitian dilaksanakan secara berdaur yang diawali dengan refleksi, perencanaan, pelaksanaan, observasi dan refleksi yang selanjutnya semakin disempurnakan pada siklus-siklus atau daur-daur selanjutnya. Penelitian tindakan kelas ini dilaksanakan di Akademi Komunitas MAPINDO pada mahasiswa program kursus semester tiga. Penelitian ini dilakukan di awal semester selama satu bulan dengan mengikuti prosedur sebagai berikut; penelitian ini menggunakan metode penelitian dari Kemmis dan Taggart dimana setiap siklusnya terdiri dari empat tahapan yaitu: (1) tahap perencanaan, (2) tahap pelaksanaan tindakan, (3) tahap observasi/evaluasi, (4) tahap refleksi. Pada penelitian ini menggunakan dua siklus dimana tiap siklusnya terbagi dalam dua kali pertemuan yaitu: (1) pertemuan ke-1 selama $2 \times 50$ menit ( 2 jam pelajaran), pertemuan ke- 2 selama $2 \times 50$ menit $(2$ jam pelajaran). Adapun prosedur pelaksanaan penelitian ini terlihat dalam gambar 1 berikut:

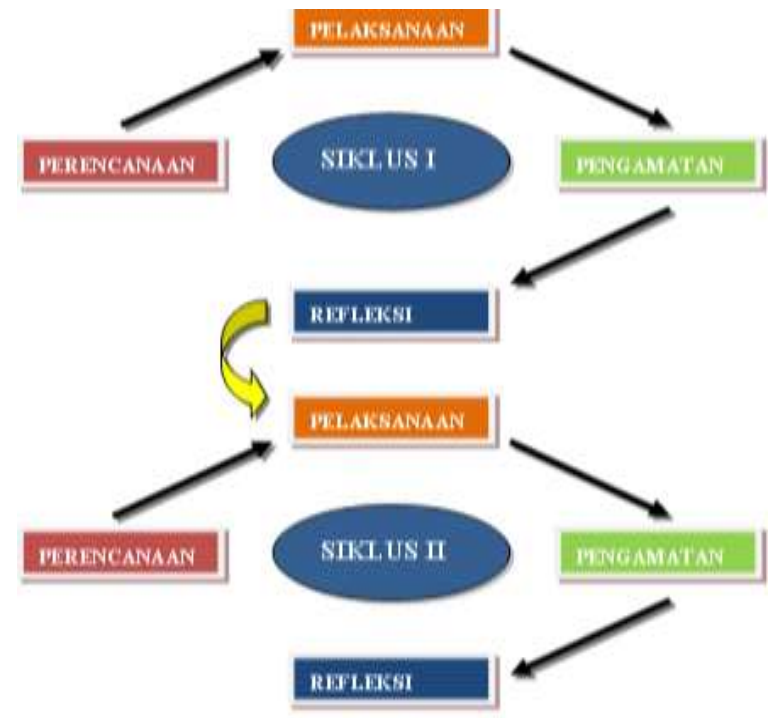

Subjek penelitian ini adalah mahasiswa kursus jurusan Akomodasi yang berjumlah 30 orang dan objek penelitian adalah peningkatan prestasi belajar Bahasa Inggris pada mahasiswa jurusan Akomodasi. Terkait dengan jenis data yang diperlukan adalah data hasil belajar dalam bentuk produk cerpen yang ditulis mahasiswa, maka data dikumpulkan dengan menilai cerpen yang ditulis oleh mahasiswa dengan fokus penilaian pada pada komponen yakni; (1) Tema, (2)Tpkoh/penokohan, (3)Latar, (4) alur, (5) amanat/pesan. Masing-masing unsur terdiri dari 5 kategori dan masing- masing diberikan skor 1. Setiap unsur diberikan skor 1 jika; 1 kategori yang dipenuhi, skor 2; jika 2 kategori yang dipenuhi, skor 3 jika; 3 kategori yang dipenuhi, skor 4 jika; 4 kategori yang dipenuhi, dan skor 5 jika; sudah 5 kategori yang dipenuhi. Data yang dikumpulkan melalui penelitian ini adalah prestasi belajar mahasiswa, selanjutnya dianalisis dengan menggunakan metode deskriptif kuantitatif, dengan menhitung rata-rata hasil belajar kemampuan mahasiswa dalam menulis cerpen dengan rumus; $R r=\frac{\text { Jumlah NilaiTotal }}{\text { jumlah siswa }}$ dan prosentase ketuntasan belajar klasikal dengan rumus; $=\frac{\text { jml siswa tuntas }}{\text { jumlah siswa }} \times 100$. 
Penelitian ini dianggap berhasi, jika hasil penelitian baik pada siklus I maupun siklus II telah mencapai indikator keberhasilan yakni jika prestasi belajar sudah mencapai minimal standar (70) atau lebih dengan ketuntasan belajar klasikal sudah mencapai minimal 85\% atau lebih. Adapun tahapan yang perlu dilakukan dalam proses pembelajaran dengan model ini adalah (1) Stimulation (stimulasi/pemberian rangsangan) ,(2) problem statement (pernyataan masalah), (3) data collection (pengumpulan data), (4) data processing (pengolahan data), (5) verification (pembuktian), dan (6) generalization (menarik kesimpulan).

\section{HASIL DAN PEMBAHASAN}

Kondisi awal subjek penelitian sebagai latar belakang dilaksanakannya penelitian tindakan kelas dengan memanfaatkan model pembelajaran Discovery Learning adalah hasil belajar menulis cerpen yang masih sangat rendah dan belum mencapai standar terutama pada mahasiswa kursus jurusan Akomodasi semester 3. Penelitian dilaksanakan di Akademi Komunitas MAPINDO dengan kondisi lingkungan sangat kondusif untuk kegiatan proses pembelajaran, motivasi belajar mahasiswa juga sangat tinggi serta prakualifikasi pengajar sangat mendukung. Namun hasil belajar kemampuan menulis teks inspiratif belum mencapai standar secara ideal, semata-mata karena disebabkan oleh kemampuan pengajar berinovasi dalam menerapkan model pembelajaran sangat terbatas. Hal ini dibuktikan dengan hasil kemampuan mahasiswa menulis cerpen seperti yang disajikan dalam table berikut ini:

Gambar 2. Grafik Histogram perkembangan kemampuan menulis cerpen

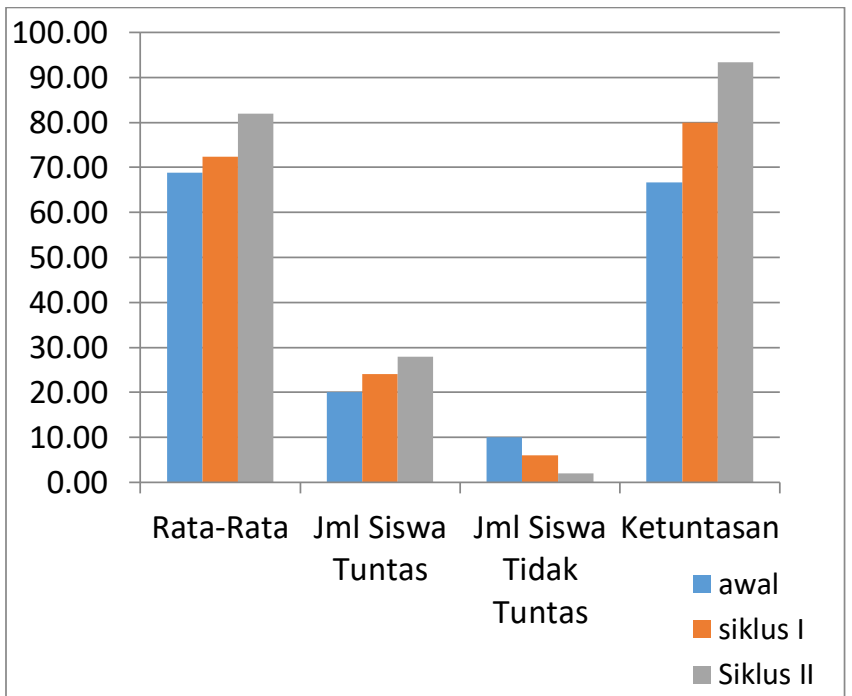

Model pembelajaran Discovery ini seperti yang disampaikan oleh Nasution (1998:2) menjelaskan keuntungan metode discovery sebagai berikut:

a. Metode ini mampu membantu mahasiswa untuk mengembangkan, memperbanyak kesiapan, serta penguasaan keterampilan dalam proses kognitif/ pengenalan siswa.

b. mahasiswa memperoleh pengetahuan yang bersifat sangat pribadi individual sehingga dapat membangkitkan kegairahan belajar mengajar mahasiswa.

c. Model ini mampu memberikan kesempatan kepada mahasiswa untuk berkembang dan maju sesuai dengan kemampuannya masing-masing.

d. Mampu mengarahkan cara mahasiswa belajar sehingga lebih memiliki keaktifan yang kuat untuk belajar lebih giat.

e. Membantu mahasiswa untuk memperkuat dan menambah kepercayaan pada diri sendiri dengan proses penemuan sendiri.

Keunggulan hasil penelitian ini disamping diperkuat oleh kajian pustaka yang mendukung, juga oleh hasil penelitian yang pernah dilaksanakan 
oleh peneliti lainnya sepert; Rega Candra Erawan dengan penelitian yang berjudul Implementasi model pembelajaran discovery Learning guna Meningkatkan Keaktifan Belajar Dan Minat Baca Siswa Kelas X TKR SMK Negeri 1 Sedayu yang hasilnya bahwa adalah model pembelajaran Discovery Learning dapat meningkatkan keaktifan belajar dan minat baca peserta didik kelas X TKR A SMKN 1 Sedayu Bantul, dibuktikan dengan meningkatnya persentase keaktifan belajar peserta didik pada siklus I menjadi sebesar $29,5 \%$ dan persentase minat baca peserta didik sebesar $78,2 \%$. Pada pelaksanaan siklus II persentase keaktifan belajar peserta didik menjadi sebesar $63,4 \%$ dan persentase minat baca peserta didik sebesar 79,2\%. Sedangkan pelaksanaan siklus III persentase keaktifan belajar peserta didik menjadi sebesar $76,5 \%$ dan persentase minat baca peserta didik sebesar 79,4\% dengan kualifikasi kualitas persentaseminat baca peserta didik "baik"pada keaktifan belajar dan minat baca peserta didik.

Yuli Rahmalia melaksanakan penelitian efektivitas model pembelajaran Discovery memperoleh hasil bahwa: Discovery sangat efektif dimanfaatkan untuk meningkatkan prestasi belajar; afektif, kognitif, dan psikomotor.

\section{PENUTUP \\ Simpulan}

Berdasarkan hasil analisis data dan pembahasan, maka dapat disimpulkan bahwa: Penerapan model pembelajaran Discovery Learning dapat meningkatkan hasil belajar menulis cerpen bagi mahasiswa program kursus jurusan Akomodasi semester tiga di Akademi Komunitas MAPINDO pada semester ganjil tahun pelajaran 2019/2020.

\section{Saran - Saran}

Berdasarkan simpulan di atas maka ada beberapa saran yang diajukan dalam penelitian ini yaitu:

1) Pengajar mata pelajaran sejawat, agar mempertimbangkan penerapan model pembelajaran Discovery Learning dalam menanggulangi kelemahan hasil belajar,

2) Pengajar mata pelajaran lain selaku pengembang dan pelaksana pembelajaran harus cermat dalam memilih model dan sumber belajar bagi mahasiswa, agar pembelajaran yang dikembangkan benar-benar mampu menyentuh substansi kebutuhan mahasiswa dan bermakna bagi mahasiswa karena setiap pembelajaran memiliki karakteristik yang sangat beragam termasuk kebutuhan belajarnya.

3) Bagi peneliti lain diharapkan melaksanakan penelitian lanjutan guna mengembangkan hasil penelitian ini terutama meneliti pada variabel-variabel yang belum sempat diteliti pada penelitian ini,

4) Bagi pengembang dan pemangku kepentingan pendidikan agar senantiasa memberikan dorongan, dukungan terhadap setiap pengajar yang memiliki kemampuan dan keinginan berinovasi dalam pembelajaran melalaui menyediakan fasilitas-fasilitas yang diperlukan.

\section{DAFTAR PUSTAKA}

Anggayana, I. A., Budasi, I. G., \& Kusuma, I. W. (2019). Social Dialectology Study of Phonology in Knowing English Student Speaking Ability. (P. Robertson, Ed.) The Asian EFL Journal, 25(5.2), 225-244.

Anggayana, I. W. A., \& Sari, N. L. K. J. P. (2018). Kemampuan Berbicara Bahasa Inggris Mahasiswa Akomodasi Perhotelan: sebuah Kajian Fonologi. Jurnal Manajemen Pelayanan Hotel, 1(1), 8-14. 
Anggayana, I. W. A., Budasi, I. G., Lin, D. A., \& Suarnajaya, I. W. (2014). Affixation of bugbug dialect: A Descriptive Study. Jurnal Pendidikan Bahasa Inggris undiksha, 1(1).

ANGGAYANA, I. W. A., NITIASIH, D. P. K., BUDASI, D. I. G., \& APPLIN, M. E. D. (2016). Developing English For Specific Purposes Course Materials for Art Shop Attendants and Street Vendors. Jurnal Pendidikan Bahasa Inggris Indonesia, 4(1).

Anggayani, N. W., \& Osin, R. F. (2018). Pengaruh Service Performance Terhadap Nilai Sekolah Kepuasan Dan Loyalitas Pelajar Pada Smk Pariwisata Triatma Jaya Tabanan. Jurnal Manajemen Pelayanan Hotel, 1(1), 28-35.

Arikunto Suharsimi,Prof.Dr., 2004. Evaluasi Program Pendidikan, Jakarta: Bumi Aksara.

Arikunto, Suharsimi. 1989. Penilaian Program Pendidikan. Proyek Pengembangan LPTK Depdikbud. Dirjen Dikti.

Asriyani, R., Suryawati, D. A., \& Anggayana, I. W. A. (2019). PENERAPAN TEKNIK ROLE PLAY DALAM MENINGKATKAN KOMPETENSI BERBICARA BAHASA INGGRIS SISWA KELAS SEBELAS TERHADAP KEANEKARAGAMAN PERSONALITY TYPES DI SMK PARIWISATA TRIATMA JAYA BADUNG. LITERA: Jurnal Litera Bahasa Dan Sastra, 5(2).

Asriyani, R., Suryawati, D. A., \& Anggayana, I. W. A. (2019, August). USING ROLE PLAY TECHNIQUES IN IMPROVING ENGLISH SPEAKING COMPETENCY ON THE PERSONALITY TYPES. In International Conference on Cultural
Studies (Vol. 2, pp. 44-48).

Budasi, I. G., \& Anggayana, I. A. (2019). Developing English for Housekeeping Materials for Students of Sun Lingua College Singaraja-Bali. The Asian EFL Journal, 23(6.2), 164179.

Depdiknas, 2006. Pedoman Pelaksanaan Penelitian Tindakan Kelas, Jakarta: Dit Prodik Dirjen PMPTK

Dimyati \& Mujiyono (1994) Belajar dan Pembelajaran, Jakarta: Depdikbud

Lindawati, N. P., Asriyani, R., \& Anggayana, I. W. A. (2018). KEMAMPUAN MENULIS KARANGAN DIALOG MELALUI MODEL PEMBELAJARAN KOOPERATIF TIPE THINK-PAIRSHARE PADA MAHASISWA JURUSAN TATA HIDANGAN DI AKADEMI KOMUNITAS MANAJEMEN PERHOTELAN INDONESIA. SINTESA.

Lindawati, N. P., Asriyani, R., \& Anggayana, I. W. A. (2019). MODEL KOOPERATIF THINK-PAIR-SHARE DALAM MENINGKATKAN KEMAMPUAN MENULIS KARANGAN DIALOG BAHASA INGGRIS MAHASISWA AKADEMI KOMUNITAS MANAJEMEN PERHOTELAN INDONESIA. LITERA: Jurnal Litera Bahasa Dan Sastra, 4(1).

Mukhlis, Abdul. (Ed). 2000. Penelitian Tindakan Kelas. Makalah PanitianPelatihan Penulisan Karya IImiah untuk Guru-guru seKabupaten Tuban.

Natawijaya Rochman,1985,Cara Belajar Siswa Aktif dan Penerapannya Dalam Metode Pembelajaran, Jakarta: Direktorat Pendidikan Dasar dan Menengah 
Osin, R. F., Kusuma, I. R. W., \& Suryawati, D. A. (2019). STRATEGI PENGEMBANGAN OBJEK WISATA KAMPUNG TRADISIONAL BENA KABUPATEN NGADA-FLORES NUSA TENGGARA TIMUR (NTT). Jurnal Ekonomi dan Pariwisata, 14(1).

Osin, R. F., Pibriari, N. P. W., \& Anggayana, I. W. A. (2019, August). BALINESE WOMEN IN SPA TOURISM IN BADUNG REGENCY. In International Conference on Cultural Studies (Vol. 2, pp. 35-38).

Redianis, N. L., Putra, A. A. B. M. A., \& Anggayana, I. W. A. (2019, August). EFFECT OF CULTURE ON BALINESE LANGUAGE USED BY EMPLOYEE HOTELS FOR FOREIGN TRAVELERS IN THE SOCIOLINGUISTIC PERSPECTIVE. In International Conference on Cultural Studies (Vol. 2, pp. 39-43).

Suryawati, D. A., \& Osin, R. F. (2019). Analisis Menu untuk Menentukan Strategi Bauran Pemasaran pada Bunut Café di Hotel White Rose Legian Kuta. Jurnal Manajemen Pelayanan Hotel, 3(1), 29-35.

Tari, N., \& Safitri, N. P. D. (2018). Pengaruh Tekhnik "Speaking Random Club" Terhadap Kemampuan Berbicara Pada Mahasiswa Program Studi Tata Hidangan Di Akademi Komunitas Mapindo Pada Tahun Akademik 2016/2017. Jurnal Manajemen Pelayanan Hotel, 1(1), 15-18. 